\title{
Sexual Dimorphism of Correlations of feet anthropometric parameters and Height (stature) among Undergraduate students of a University, Western Nigeria.
}

\author{
${ }^{1}$ Dr Keme Ebimobo Tobias. ${ }^{2}$ Dr Mukoro Duke George, ${ }^{3}$ Mr. Ezeuko Vitalis, \\ ${ }^{4}$ Prof Dorothea Baxter-Grillo \\ ${ }^{1}$ B.Med Sci,MBBs,M.Sc, ${ }^{2}$ B.Sc.MBBs,ATlScert,DTM\&Hliverpool,${ }^{3}$ B.S.c., M.Sc, PhD in view, \\ ${ }^{4}$ LRCPI, LRCSI, LLMI, DCH, Ph.D, FMCS, FAAS \\ ${ }^{1 .}$ Niger-Delta University Teaching Hospital, Okolobiri, Bayelsa, Nigeria \\ 2. St George's University. School Of Medicine, West Indies. \\ 3. University of Benin, Benin, Edo state, Nigeria
}

\begin{abstract}
:
Introduction: Today, the use of arthopometer has become versatile including radiological investigation, forensic medicine and crime investigation. Skeletal anthropometric parameters is influenced by a number of factors producing variations between different geographical areas, it is desirable to have some means of giving quantitative expression to variations to which such traits exhibit.. The aim of the study was to evaluate correlate foot anthropometric parameters to height (stature) and determine any sexual dimorphism among the University of Benin Undergraduates. Result from this study can be used as data base for forensic investigations and other anthropometric studies in this locality.

Material and methods: A total number of five hundred (500) subjects aged between 18-26 comprising of 250 males and 250 females were randomly selected. The parameters obtained from the participants include: age, gender, foot length, standing height of subjects using sliding vernier caliper, and rigid meter rule. The analyses were done using computer software known as the Statistical Package for Social Sciences (SPSS) version 17.0. The results were reported as Mean+Standard error. The results were subjected to students T-test and person's correlation co-efficient as appropriate.

Results.: The results revealed that male foot length, height and breath were significantly higher that their female counterpacts.Secondly foot length remain the best correction for height determination among the other parameters. The linear regression equations were derived for estimation of height (stature) from foot length and foot breadth and in both genders. Gender combined was Height $=4.671$ (foot length) +47.79 . Male alone was Height $=3.858($ foot length $)+71.19$. Females alone was Height $=3.578($ foot length $)+73.15$. Other anthropometric parameters revealed less correlation.

Conclusion: The anthropometric data provided serves as a template for the locality from which this study was carried out, and confirms that there are geographical and sexual dimorphism in anthropometric parameters, therefore should be considered in forensic or criminal investigations.
\end{abstract}

Keywords: Anthropometry, Foot and breath, Height, Male ,Female

\section{Introduction}

Skeletal development is influenced by a number of factors producing differences in skeletal proportions between different geographical areas, it is desirable to have some means of giving quantitative expression to variations which such traits exhibit (Krishan \& Kumar, 2007).

Anthropometry is highly objective and reliable in the hands of trained anthropometrists (Krishan \& Kumar, 2007). The significance and importance of somatometry, cephalometry, craniometry and osteometry in the identification of human remains have been described by a new term, 'forensic anthropometry' .

The use of anthropometry in the field of forensic science and medicine dates back to 1882 when Alphonse Bertillon, a French police expert invented a system of criminal identification based on anthropometric measurements. His system was based on three fundamental ideas- the fixed condition of the bone system from the age of twenty till death; the extreme diversity of dimensions present in the skeleton of one individual compared to those in another; the ease and relative precision with which certain dimensions of the bone structure of a living person can be measured using simply constructed callipers. This system of identification spread rapidly through much of the world but the system was not accepted much in view of some major drawbacks and discovery of other identification systems e.g. dactylography (Moenssens, 1995). 
The use of anthropometry arose due to several sets of circumstances i.e. Natural, intentional and accidental (war dead cases, air crash, road and train accidents, earth quake, flood, fire; deliberate mutilation, disfigurement, pounding, gouging etc. of the dead body) (Krogman, 1962; Krogman and Iscan, 1986)

Anthropometry deciphers varying degree of difference or similarity and state how much confidence can be placed in this interpretation (Adams and Byrd, 2002). Anthropometry enables the law enforcement agencies to achieve the ultimate goal of personal identification (Krishan \& Kumar, 2007).

Ascertaining sex and estimation of stature from incomplete skeletal and decomposing bodies as in physical anthropology and forensic science (Daniel et al; 2005) has become useful in recent times due to mass disasters like plane crash, mass suicide, tsunamis, forest fires, earth quakes (Snell, 2000).

There are various ways to estimate stature from bones but the easiest and the most reliable method is by regression analysis (Iscan, 2001; Iscan, 2005). The major difficulty in developing a stature estimation formula is the non-availability of skeletal series with known body height data (Iscan, 2005).

Various studies conducted on the estimation of stature indicate that every part of the skeleton has been used for estimation (Krishan 2007). One of the foremost studies on estimation of stature from long bones of American whites and blacks is by Trotter and Gleser 1952. Since then, scientists have carried out extensive work on the estimation of stature from a variety of bones throughout the world with variable degree of success. Each worker has derived his own formula for calculating the stature from long bones. However, foot measurement has not frequently been used for this. It was Rutishauser (1968) who for the first time showed that reliability of prediction of height from foot length was as high as that from long bones.

The aim of the study was to evaluate correlate foot anthropometric parameters to height (stature) and determine any sexual dimorphism among the University of Benin Undergraduates. Result from this study can be used as data base for forensic investigations and other anthropometric studies in this locality.

\section{Material And Method}

A total number of five hundred (500) subjects aged between 18-26 comprising of 250 males and 250 females were randomly selected undergraduate students of the University of Benin, belonging to various religions who voluntarily agreed to be measured. The parameters obtained from the participants include: age, gender, foot length, standing height of subjects. Instrument used included Sliding vernier caliper, and rigid meter rule.

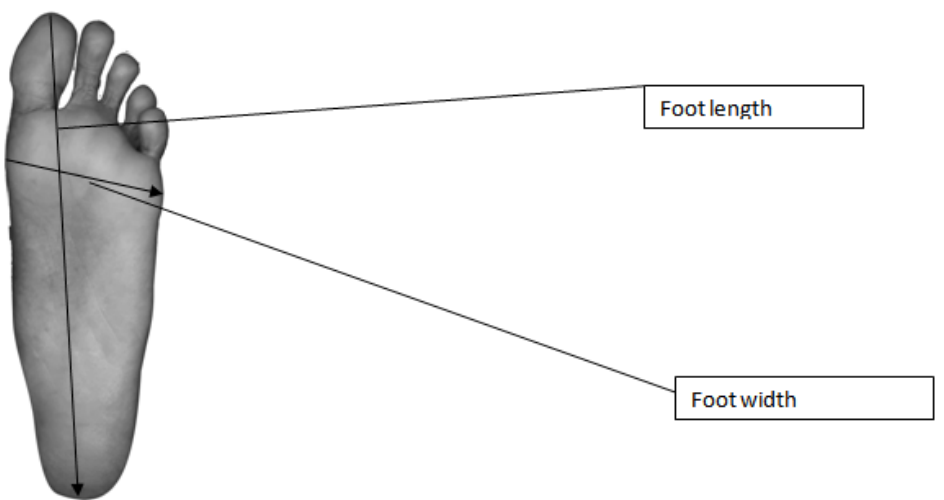

Figure 1; LENGTH AND BREATH MEASUREMENTS

Foot length -This is the length from the heel of the foot to the tip of the great toe. This secludes nails (Agnihotri AK et al,2007).

1. Foot breadth-This is the straight distance from the most medial point on the head of the first metatarsal to the most laterally placed point on the head of the fifth metatarsal (Agnihotri AK et al,2007).

2. Standing height -This is the height from the vertex of the skull to the feet of a subject standing erect in the anatomical position. 


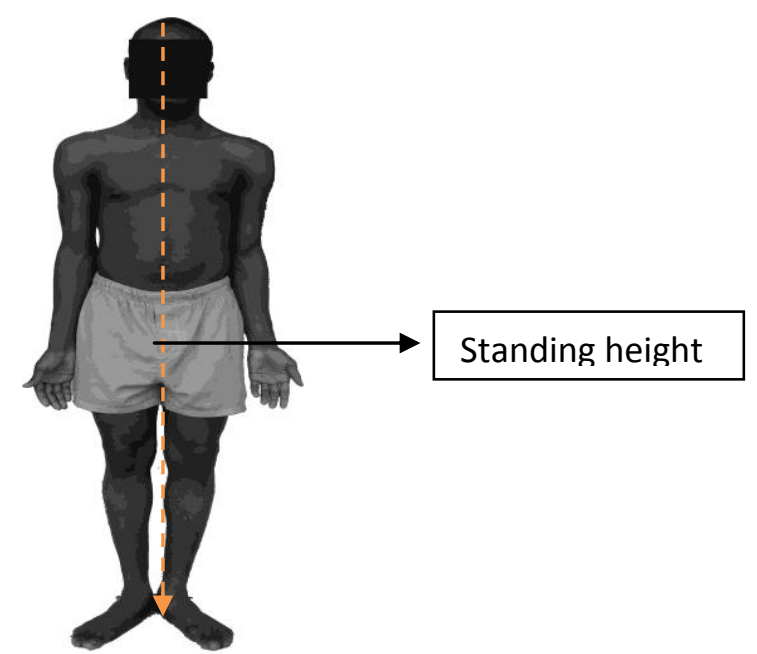

The analyses were done using computer software known as the Statistical Package for Social Sciences (SPSS) version 17.0. The results were reported as Mean \pm Standard error. The results were compared in both sexes using the students' T-test (2 samples, unpaired, assuming equal variance). The foot dimensions were correlated with stature using Pearson's product moment correlation. The differences were considered statistically significant at $99 \%$ or $95 \%$ confidence levels i.e. when probability is less than $0.01(\mathrm{P}<0.01)$ or when probability is less than $0.05(\mathrm{P}<0.05)$.

III. Results:

Figure 2: Measurement Of Height

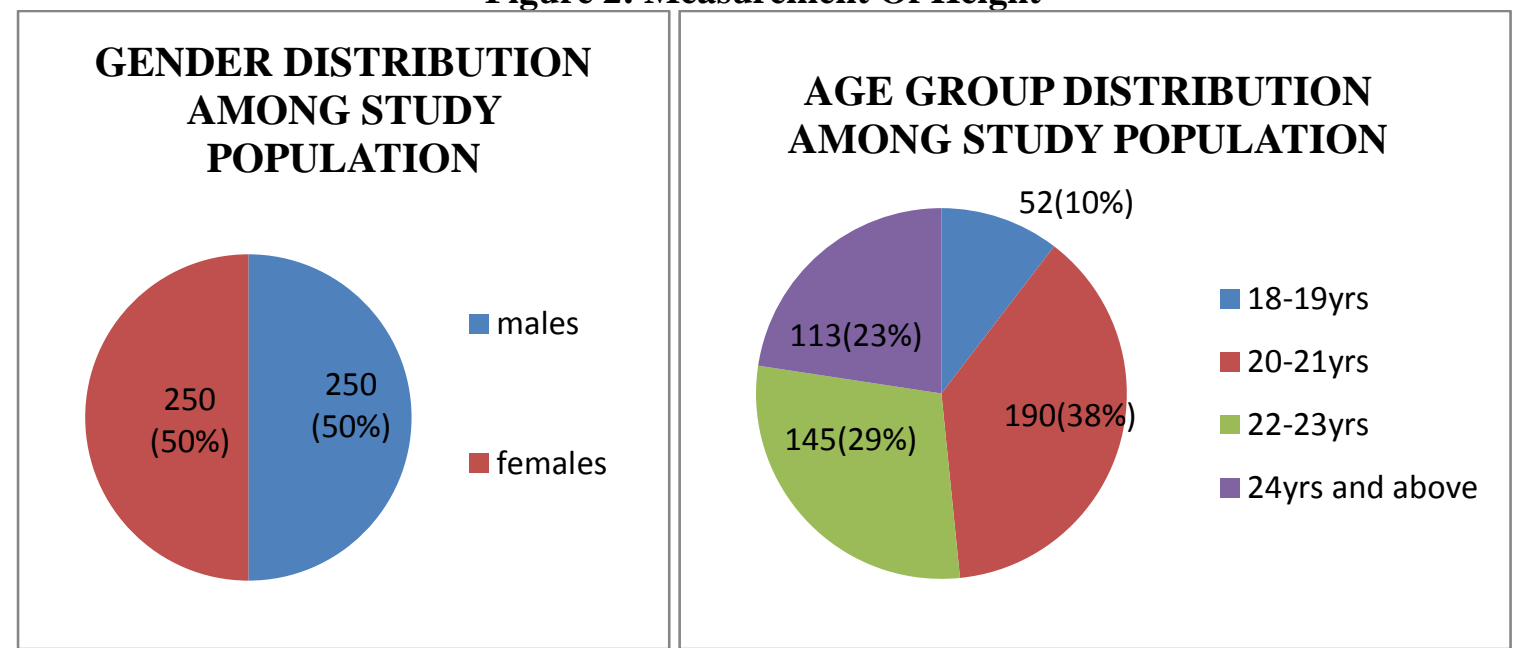

Figure 3: Pie Chart Showing Gender

Figure 4: Pie Chart Showing Age Distribution

\section{Distribution}

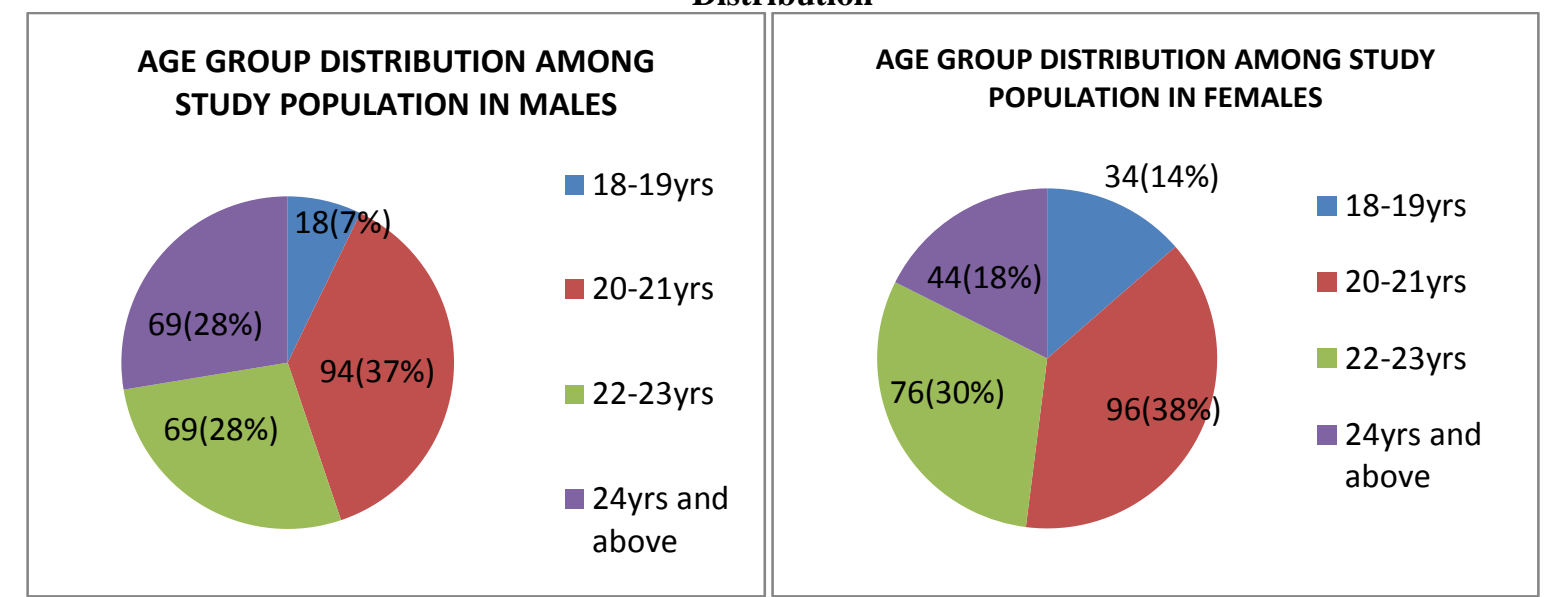

Figure 5: Pie Chart Showing Age Group

Figure 6: Pie Chart Showing Age Group Distribution Distribution Among Study Population

Among Study Population In Females In Males 
Table 1: Showing The Mean+Standard Error Of All The Parameters Studied

\begin{tabular}{|l|l|l|l|l|}
\hline & all & males & Females & Probability \\
\hline Age & $21.8 \pm 0.1$ & $22.1 \pm 0.1$ & $21.6 \pm 0.1$ & $0.001^{*}$ \\
\hline Height & $168.0 \pm 0.4$ & $175.6 \pm 0.5$ & $161.4 \pm 0.4$ & $0.000^{*}$ \\
\hline foot length & $25.7 \pm 0.1$ & $26.8 \pm 0.9$ & $24.7 \pm 0.1$ & $0.000^{*}$ \\
\hline foot breadth & $10.3 \pm 0.1$ & $11.0 \pm 0.1$ & $9.6 \pm 0.1$ & $0.000^{*}$ \\
\hline foot index & $40.0 \pm 0.1$ & $41.0 \pm 0.2$ & $39.1 \pm 0.2$ & $0.000^{*}$ \\
\hline
\end{tabular}

*Significant

All the parameters studied was significantly higher $(\mathrm{P}<0.01)$ in males than females.

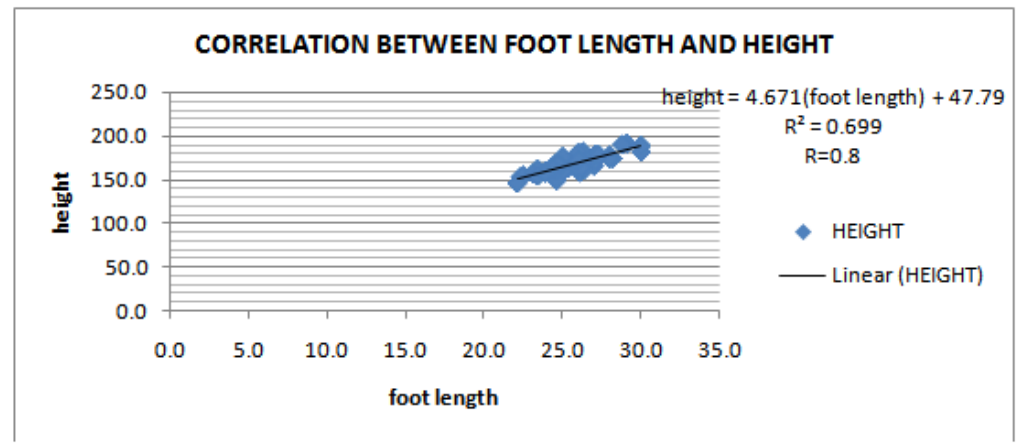

Figure 7: Scattergram Showing Correlation Between Foot Length And Height

From figure 7 above, there was a statistically significant positive correlation $(\mathrm{P}<0.05)$ between foot length and height.

Heigh

$=\quad 4.671$ (foot

length)

47.79

coefficient of determination $\left(\mathrm{R}^{2}\right)=0.699$

Coefficient of correlation $(\mathrm{R})=0.8$

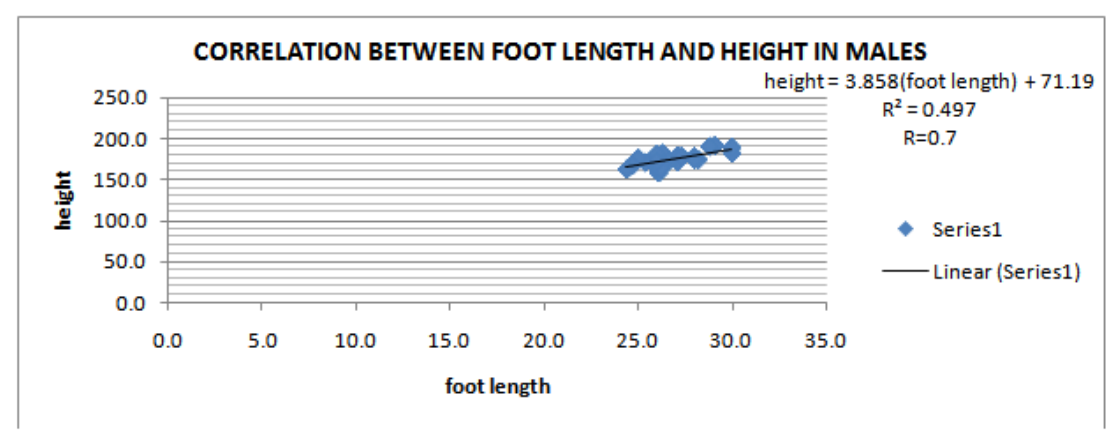

Figure 8: Scattergram Showing Correlation Between Foot Length And Height In Males

From figure 8 above, there was a statistically significant positive correlation $(\mathrm{P}<0.05)$ between foot length and height in males.
Height
$=\quad 3.858$ (foot
length)
71.19

coefficient of determination $\left(R^{2}\right)=0.497$

Coefficient of correlation $(\mathrm{R})=0.7$ 


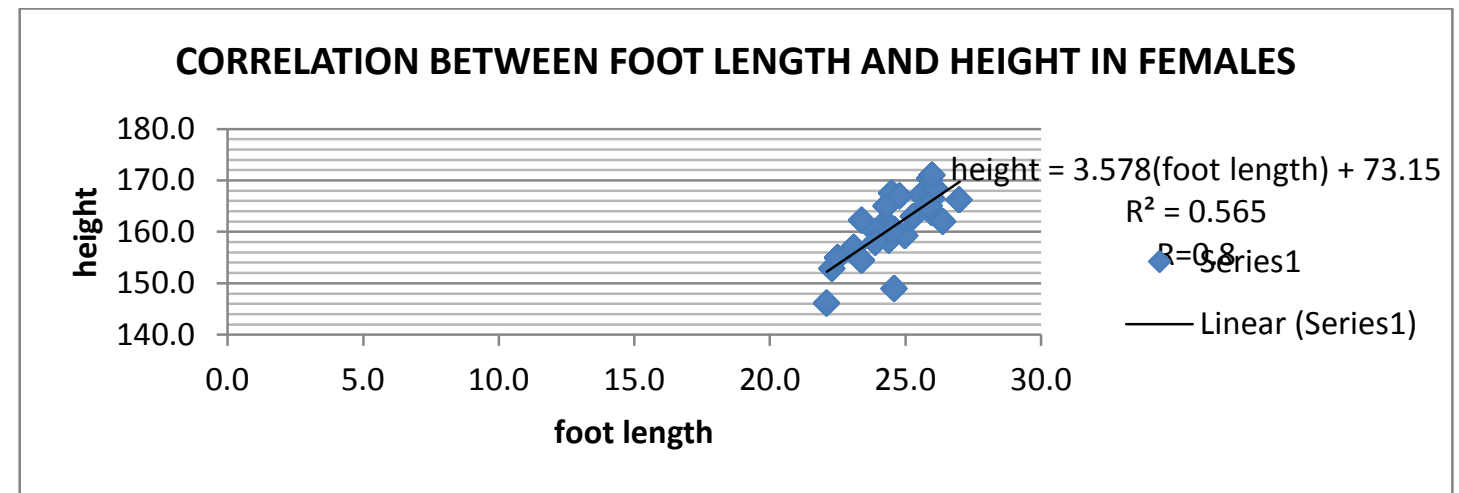

Figure 9: Scattergram Showing Correlation Between Foot Length And Height In Females

From figure 4.25 above, there was a statistically significant positive correlation $(\mathrm{P}<0.05)$ between foot length and height in females.
Height
$=\quad 3.578($ foot
length)
73.15

coefficient of determination $\left(\mathrm{R}^{2}\right)=0.565$

Coefficient of correlation $(\mathrm{R})=0.8$

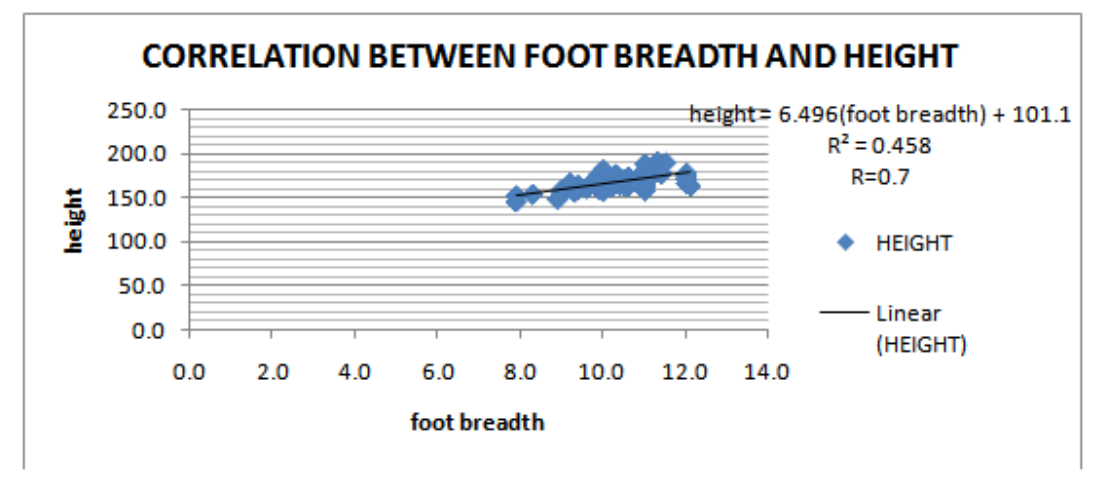

Figure 4.27: Scattergram Showing Correlation Between Foot Breadth And Height

From figure 4.27 above, there was a statistically significant positive correlation $(\mathrm{P}<0.05)$ between foot breadth and height.

$\begin{array}{llll}\text { Height } & 6.497(\text { foot } & \text { breadth } & +\end{array}$

coefficient of determination $\left(\mathrm{R}^{2}\right)=0.458$

Coefficient of correlation $(\mathrm{R})=0.7$ 


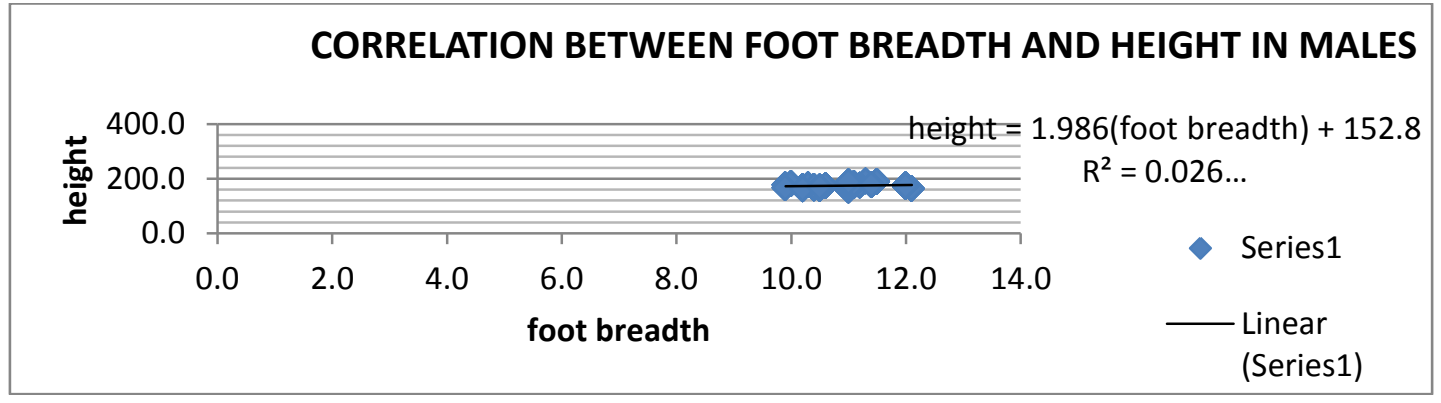

Figure 4.28: Scattergram Showing Correlation Between Foot Breadth And Height In Males

From figure 4.28 above, there was no statistically significant correlation $(\mathrm{P}>0.05)$ between foot breadth and height in males.
Height
$=\quad 1.986$ (foot
breadth)
$+$
152.8
coefficient of determination $\left(\mathrm{R}^{2}\right)=0.026$

Coefficient of correlation $(\mathrm{R})=0.2$

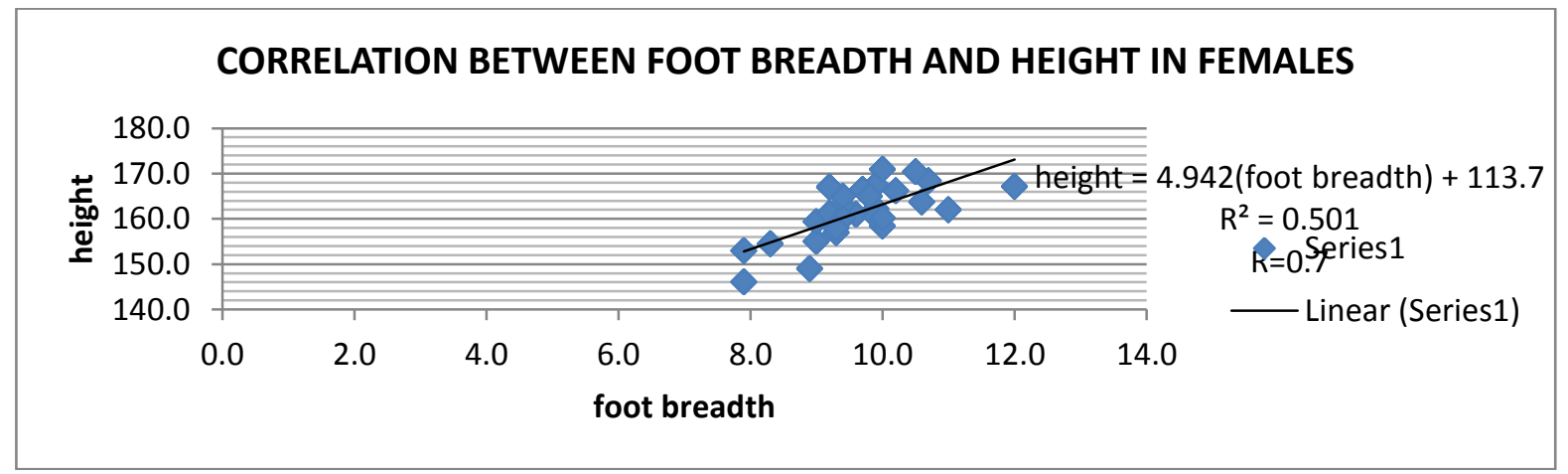

Figure 4.29: Scattergram Correlation Between Foot Breadth And Height In Females

From figure 4.29 above, there was a statistically significant positive correlation $(\mathrm{P}<0.05)$ between foot breadth and height in females.

$\begin{array}{llll}\text { Height } & \text { 4.942(foot } & \text { breadth } & +\end{array}$

coefficient of determination $\left(\mathrm{R}^{2}\right)=0.501$

Coefficient of correlation $(\mathrm{R})=0.7$

The linear regression equations were derived for estimation of stature from foot length and foot breadth and foot index in both genders. From a combined gender value, the regression formula for height estimation from foot length was Height $=4.671$ (foot length) +47.79 . There was a statistically significant positive correlation $(\mathrm{P}<0.05, \mathrm{R}=0.8)$ between foot length and height. In males, the regression formula for height estimation from foot length was Height $=3.858$ (foot length) +71.19 . There was a statistically significant positive correlation $(\mathrm{P}<0.05,0.7)$ between foot length and height in males. In females, the regression formula for height estimation from foot length was Height $=3.578$ (foot length) +73.15 . There was a statistically significant positive correlation $(\mathrm{P}<0.05, \mathrm{R}=0.8)$ between foot length and height in females.

When gender was combined, the regression formula for height estimation from foot breadth was Height $=6.497$ (foot breadth $)+101.1$. There was a statistically significant positive correlation $(\mathrm{P}<0.05, \mathrm{R}=0.7)$ between foot breadth and height. In males, the regression formula for height estimation from foot breadth was Height $=$ 1.986 (foot breadth) +152.8 . There was no statistically significant correlation $(\mathrm{P}>0.05, \mathrm{R}=0.2)$ between foot breadth and height in males. In females, the regression formula for height estimation from foot breadth was Height $=4.942$ (foot breadth $)+113.7$. There was a statistically significant positive correlation $(\mathrm{P}<0.05, \mathrm{R}=0.7)$ between foot breadth and height in females.

When gender was combined, the regression formula for height estimation from foot index was Height $=0.613$ (foot index $)+143.5$. There was no statistically significant correlation $(\mathrm{P}>0.05, \mathrm{R}=0.2)$ between foot index and height. In males, the regression formula for height estimation from foot index was Height $=-$ 1.174 (foot index $)+222.7$. There was statistically significant negative correlation $(\mathrm{P}>0.05, \mathrm{R}=-0.4)$ between foot index and height in males. In females, the regression formula for height estimation from index was Height $=$ 0.993 (foot index $)+122.6$. There was statistically significant positive correlation $(\mathrm{P}<0.05, \mathrm{R}=0.4)$ between foot index and height in females. 


\section{Discussion}

All the parameters studied was significantly higher $(\mathrm{P}<0.01)$ in males than females. This is in agreement with an earlier study by Ibinabo and Didia (2009) that showed that males had significantly higher values of foot length and foot breadth than females $(\mathrm{p}<0.001)$. Sen and Ghosh also confirmed this among Rajbanshi, an indigenous population of North Bengal. Their study indicated that female Rajbanshi individuals exhibit shorter stature and smaller feet than their male counterparts.

The males height was significantly higher $(\mathrm{P}<0.01)$ than the female height. The males foot length was significantly higher $(\mathrm{P}<0.01)$ than the female foot length. The male foot breadth was significantly higher $(\mathrm{P}<0.01)$ than the female foot breadth. The male foot breadth was significantly higher $(\mathrm{P}<0.05)$ than the female foot breadth at 95\% probability level. Ibinabo and Didia (2009) had placed the mean foot length of adult Nigerians (18 years and above) at $26.9 \mathrm{~cm}$ for males and $25.0 \mathrm{~cm}$ for females while Didia and Obikili (2006) placed it at $27.1 \mathrm{~cm}$ for males and $25.1 \mathrm{~cm}$ for females.

Ashizawa et al; (1997) and Wunderlich and Cavanagh (2001) reported in their respective study showed that males have longer and broader feet than females for a given stature. The larger foot dimension of males in this study in comparison with females is in agreement with this postulation. Besides, Obikili and Didia (2006) in their study on the Nigeria population also found that males, have broader and longer foot dimensions than females.

The higher correlation coefficient between stature and foot length was greater than that stature and foot breadth and pointing to the fact that foot length, rather than foot breadth, is more accurate in estimating stature. This is in agreement with the work done by Krishan and Sharma (2007) and the work done by Sen and Ghosh (2008) which indicated that the foot length provides highest reliability and accuracy in estimating stature of an unknown individual.

Macdonnel (1901) studied 3000 English criminals and derived regression formulae for estimation of stature from foot length, $166.457+4.031$ (foot-25.688) $+/-2.9 \mathrm{cms}$. However, sex was not been given due consideration in this study. Qamra et al; (1980) computed linear regression equations for estimating stature from either foot length or foot breadth of 1015 subjects between the ages of 17-32 years. After testing validity of equations, foot length was found to be more suitable. The variability derived in this present study could be due to the former study being conducted on a particular region whereas our study involved a diverse group. Qamra et al; (1986) suggested that a true relationship existed only between foot length and stature, and the relationship in other combination of variables was affected to a great extent by foot length alone. Giles et al; (1991) also suggested that foot length displays a biological correlation with height and the latter can be estimated from foot length. Gordon et al; (1992) estimated stature from foot dimensions and models containing both foot length and foot breadth were found to be significantly better than those containing only foot length. In this study, strong relationship was established between foot/boot lengths. Singh and Phookan (1993) examined Thai male population of Assam and suggested foot length to be a better indicator of stature than foot breadth. Zeybek et al; (2008) developed formulae for estimation of the stature and gender through foot measurements. They derived multiple regression formulae for stature estimation and logistic regression analysis for gender estimation using foot measurements.

The foot dimension in males and females in this study is comparatively larger than Caucasian values (Wolanski, 1962; Stranisev et al; 1970, Dupartius et al; 1972). This finding is in accord with theoretical expectation that populations living in warm climates would have longer arms and legs than populations living in cold environments. Schreider (1975) reported that tropical climate dwellers have longer limbs than temperate climate dwellers. Large foot dimensions are adaptation to tropical environment as they increase the surface area available for heat loss.

On the clinical application of foot dimension, Gorman et al; (1997) in their study on the relationship between shoe size in women and mode of delivery noted that a woman with a small shoe size did not have a higher chance of being delivered by Caesarean section. Schultz et al; (1998) reported that many girls with Rett Syndrome had small feet for height. Besides, Rodier et al; (1997) noted that children with autism had smaller feet compared with the control group. This study like that of Obikili and Didia (2006) provides added reference standard of foot dimension for the Nigerian population and form a basis for further studies on clinical application of foot dimension. In most published data of foot anthropometry, none had reported any form of significant asymmetry in normal individuals. Hence efforts was made in this present study to measure right and left foot and the average taken.

\section{Conclusion.}

The anthropometric data provided serves as a template for the locality from which this study was carried out, and confirms that there are geographical and sexual dimorphism in anthropometric parameters, therefore should be considered in forensic or criminal investigations. 


\section{References}

[1] Ashizawa K, Kumakura C, Kusumato A, Narasaki S 1997. 'Relative foot size and shape to general body size in Japanese, Filipians and Japanese with special reference to habitual foot war types'. Annals Human Biology 24:117-29.

[2] Daniel MTF, Kevin JH, Roshni DL 2005'Sexual dimorphism in foot length proportionate to stature'Annals of Human Biology; 32 (1): 4459 .

[3] Didia BC, Omu FT, Obuoforibo AA 1987, 'The use of foot print contact index II for classification of flat feet in a Nigerian population', Foot and Ankle society. 8(4): 0192-0211.

[4] Dupartius A, Dupartius CW, Casey AE 1972, 'Physical anthropology of young adult females in Slieve Loughter, South West Island' AMJ Phys Anthropol 37: 435

[5] Giles E, Vallaneligham PH 1991. 'Height estimation from foot and shoe print length', J Forensic Sci. 36(4): 1134-1151.

[6] Gorden CC and Buikstra JE 1992. 'Linear models for the prediction of stature from foot and boot dimensions', J. Forensic Sci. 37(3):771-782

[7] Iscan MY 2001, ' Global forensic anthropology in the 21st century (Editorial)' Forensic Sci Int 111997:1-6.

[8] Iscan MY 2005, 'Forensic anthropology of sex and body size (Editorial)'. Forensic Sci Int 2005;147:107-112.

[9] Krishan K 2007, 'Anthropometry in Forensic Medicine and Forensic Science-'Forensic Anthropometry' . The Internet Journal of Forensic Science. Volume 2 Number 1.

[10] Krishan K, Kumar R 2007. Determination of stature from cephalo-facial dimensions in a north Indian population. Leg Med (Tokyo).

[11] Krishan K, Sharma A 2007. 'Estimation of stature from dimensions of hands and feet in a North Indian population', J Forensic Legal Med 14:327-332.

[12] Krogman WM 1962, 'The Human Skeleton in Forensic Medicine' Springfield, Illinois, U.S.A. Charles C. Thomas Pub Ltd.

[13] Krogman WM, Iscan YM 1986, 'The Human Skeleton in Forensic Medicine' (2nd edition) Springfield, Illinois, U.S.A. Charles C. Thomas Pub Ltd.

[14] Macdonnel WR 1901. 'On criminal anthropometry and the identification of criminals', Biometrika 1:177-227.

[15] Moenssens AA 1995. 'Fingerprinting Techniques- Inbau Law Enforcement Series, Radnor, Pennsylvania' Chilton Book Company.

[16] Obikili, EN, Didia BC 2006, 'Foot Dimensions of a young adult Nigerian population'. Port Harcourt Medical Journal, Vol. 1(1):2224.

[17] Qamra SR, Deodar SD, Jit I 1986, 'A metric study of feet of north-west Indians and its relationships to body height and weight', Ind J phys Anthropol Hum Genet. 12(2):131-138.

[18] Rodier PM, Ingram JL, Tisdale B, Croog VJ 1997, 'Linking Etiologies in Humans and Animal Models: Studies of Autism', Reproductive Toxicology 11:417-422.

[19] Rutishauser IHE, 1968,'Prediction of height from foot length: use of measurement in field survey'. Arch. Dis. Child.; 43 : 310.

[20] Scherider E 1975, 'Ecology rules and body heat regulation in man' Nature 179: 915 - 916.

[21] Schultz R, Glaze D, Motil K, Hebert D, Percy A 1998, 'Hand and foot growth failure in Rett syndrome', J Child Neurol, February, vol. 13 no. 2 71-74.

[22] Sen J, Ghosh S 2008, 'Estimation of stature from foot length and foot breadth among the Rajbanshi: An indigenous population of North Bengal' Forensic Science International 181 (1-3):55e1-e6.

[23] Singh TS, Phookan MN 1993, 'Stature and foot size in four Thai communities of Assam, India' Anthropol ANZ 51(4): 349 - 355.

[24] Snell, R. 2000. Clinical Anatomy for medical students, 6th Ed.,Lippincott Williams and Wilkins,Philadelphia. pp 91, 591-595.

[25] Stranisev D, Pavlons Karapetrov G, Kerrmikov L, Petrov I 1970, Somatometrische Tabellen folia Medical. 12:1-4 and 148-157.

[26] Trotter M, Gleser GC 1952, 'Estimation of stature from long bones of American Whites and Negroes', Am J Phys Anthropol 10:463-514.

[27] Wolanski N 1962, 'Kinetics and dynamic of growth and differentiation in body proportions in children and young people from Warsaw (aged 3 to 20 years). Pantroswong zaklad wydwnectw Lekarskich, Warsaw.

[28] Wunderlich RE \& Cavanagh PR. 2001, 'Gender differences in adult foot shape: Implications for shoe design',Med Sci Sports Exerc;33:605-611

[29] Zeybek G, Ergur I, Demiroglu Z 2008. 'Stature and gender estimation using foot measurements', Forensic Sci Int. 181:54.e1-54.e5. 